
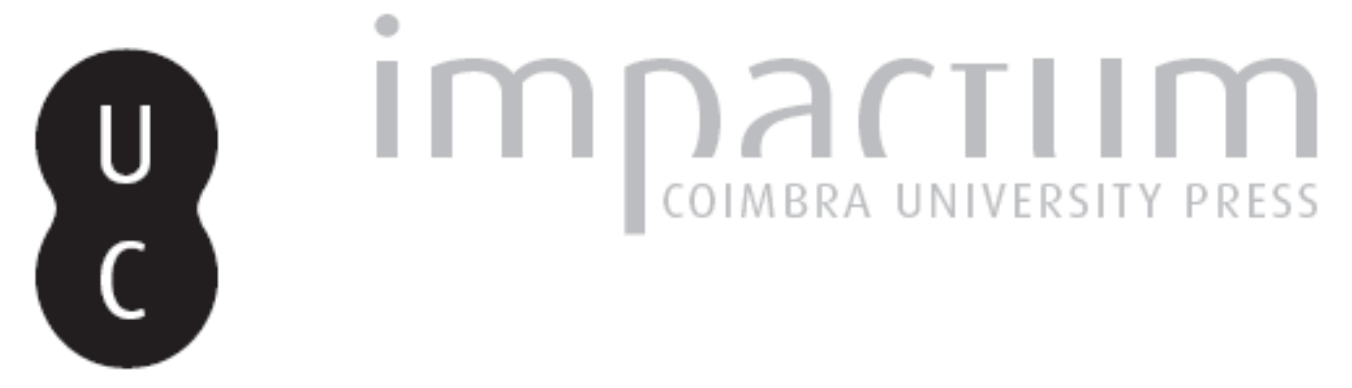

\title{
Linguagem, mito e enigma
}

\section{Autor(es): $\quad$ Serra, Ordep}

Publicado por: Annablume Clássica; Imprensa da Universidade de Coimbra

URL persistente:

URI:http://hdl.handle.net/10316.2/24349

DOI:

DOI:http://dx.doi.org/10.14195/1984-249X_8_13

Accessed : $\quad$ 26-Apr-2023 12:10:03

A navegação consulta e descarregamento dos títulos inseridos nas Bibliotecas Digitais UC Digitalis, UC Pombalina e UC Impactum, pressupõem a aceitação plena e sem reservas dos Termos e Condições de Uso destas Bibliotecas Digitais, disponíveis em https://digitalis.uc.pt/pt-pt/termos.

Conforme exposto nos referidos Termos e Condições de Uso, o descarregamento de títulos de acesso restrito requer uma licença válida de autorização devendo o utilizador aceder ao(s) documento(s) a partir de um endereço de IP da instituição detentora da supramencionada licença.

Ao utilizador é apenas permitido o descarregamento para uso pessoal, pelo que o emprego do(s) título(s) descarregado(s) para outro fim, designadamente comercial, carece de autorização do respetivo autor ou editor da obra.

Na medida em que todas as obras da UC Digitalis se encontram protegidas pelo Código do Direito de Autor e Direitos Conexos e demais legislação aplicável, toda a cópia, parcial ou total, deste documento, nos casos em que é legalmente admitida, deverá conter ou fazer-se acompanhar por este aviso.

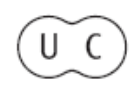


jan.2012

issn $2179-4960$

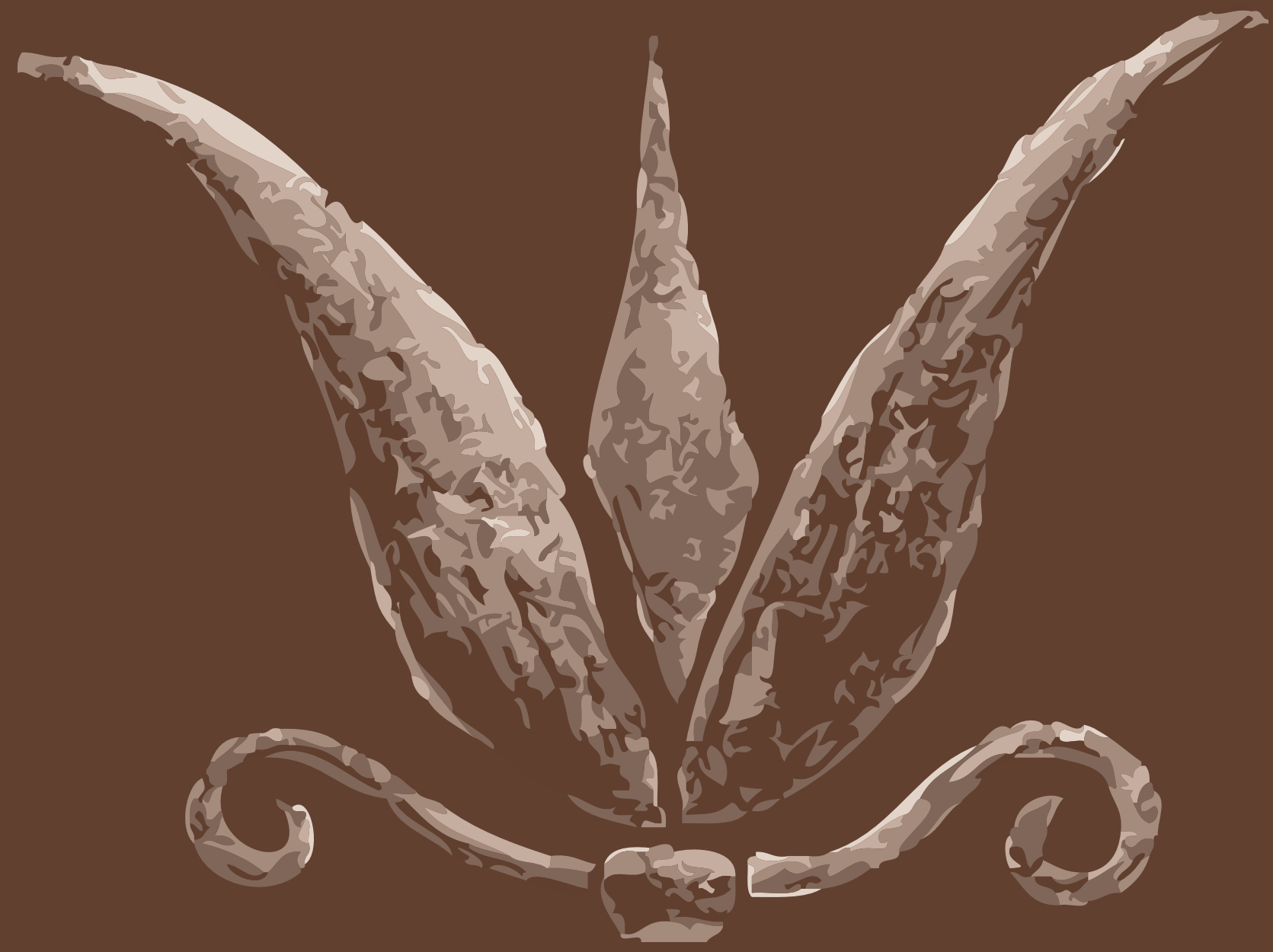

R E V I S T A
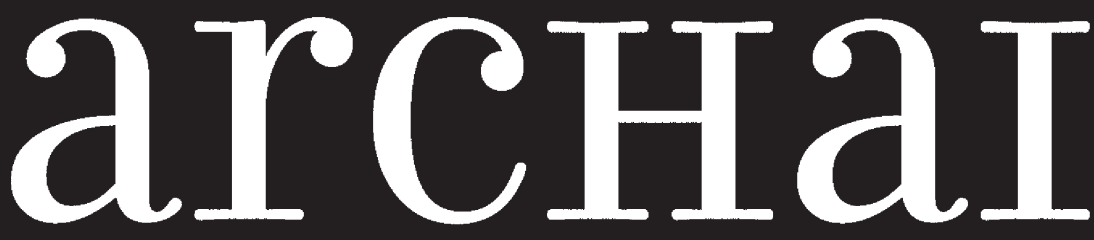

AS ORIGENS DO PENSAMENTO OCIDENTAL

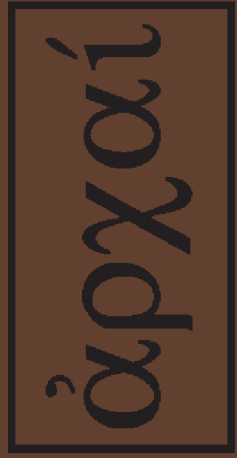

ARCHAI JOURNAL: ON THE ORIGINS OF WESTERN THOUGHT
arcHaI

AS ORIGENS DO PENSAMENTO OCIDENTA.

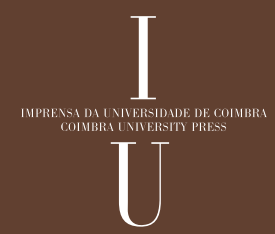

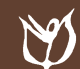




\section{LINGUAGEM, MITO E ENIGMA}

SERRA, 0. (2012). "Linguagem, mito e enigma". Archai n. 8, jan-jun 2012, pp.115-128.

RESUMO: Neste artigo começo evocando a tese de Schelling, exposta em seu "Philosophie der Mythologie", acerca da relação original que associaria o surgimento das diferentes mitologias (de diferentes povos) a uma crise da linguagem humana comum, crise que determinaria seu colapso. Passo em seguida ao exame de famosas obsrvações de Lévi-Strauss sobre a origem da linguagem, mostrando que a maneira como ele concebe o processo de designação ecoca o antigo modelo do symbállein $e$ a estrutura simbólica do enigma. Sublinho a importância da ideia de enigma na teoria levistraussiana pertinente a incesto, mito e linguagem. Por fim, discuto o chamado "discurso enigmático" das sentenças de Heráclito seguindo nisso a trilha da interpretação de Eudoro de Sousa da filosofia heracliteana.

PALAVRAS-CHAVE: Mito, enigma, linguagem, aporia, Lévi-Strauss, Eudoro de Sousa, Schelling, Heráclito

Abstract: In this article I begin evoking Schelling's thesis exposed in his book Philosophie der Mythologie about the original relation that should have united the origin of the mythical discourses (of the different world mythologies) to the appearance of different idioms as a result of a crisis affecting human ancient common language and determining its collapse. I proceed to examine Lévi-Strauss' famous observations about the origin of human language showing how the way he conceives the process of designation evokes ancient ideas about symbállein and the symbolic structure of enigma. I stress the importance of the idea of aenigma in Levi'Strauss theories about incest, myth and language. Finally I discuss the meaning of the so called enigmatic discourse of Heraclitus following the path of Eudoro de Sousa's interpretation of Heraclitean philosophy.

KEYWORDS: Myth, enigma, language, aporia, Lévi-Strauss, Eudoro de Sousa, Schelling, Heraclitus

Ordep Serra*

* Universidade Federal da Bahia. Salvador. Bahia.
Segundo Lévi-Strauss afirmou, na sua famosa Introdução à obra de Marcel Mauss, a aparição da linguagem deu-se de uma vez, de forma imediata e cogente, abrindo caminho para a longa jornada do conhecimento. Ora, no espaço criado por essa aparição, na clareira do verbo onde os mitos florescem, eles parecem ter certa precedência entre os discursos feitos memoráveis: seriam, talvez, os primeiros a manter-se com longa duração na memória social. Pelo menos, é o que tudo indica. Em todo caso, ninguém duvida de que eles antecederam as construções da filosofia, da história, da ciência. Cabe a pergunta: Que correspondência existe entre a floração dos mitos e a aparição da linguagem (à parte o fato de que os mitos exigem expressão verbal)? É possível estabelecer uma relação profunda entre essas coisas? Começarei por abordar a resposta que deu a essas questões um filósofo que Lévi-Strauss reconhece tê-lo influenciado em sua reflexão sobre mitologia.

A ideia de que o processo mitopoético "revive" ou "encarna" o drama da linguagem achou expressão singular em uma tese de Schelling, exposta mythico modo na sua Philosophie der Mythologie. No texto de Schelling - cujo núcleo é a exegese mitológica de um mito, o conto bíblico da Torre de Babel -, uma crise da consciência humana desertada pelo princípio divino (e assim ferida em sua unidade origi- 
nária) acarretou a variação dos idiomas, a dispersão do Verbo. Depois dessa ruptura - imaginou o filósofo - os humanos divididos lograram (quase todos) uma saída - precária e incompleta, mas de algum modo eficaz - do torpor obnubilante da grande perda. Lograram-no graças ao florescimento das mitologias, numa espécie de revelação necessariamente múltipla, já que correspondente à diferenciação das culturas. 0 surto das míticas diferenciadas, correlato ao despontar das distintas formações idiomáticas, incorporava uma vaga reminiscência do princípio já oculto - e essa memória crepuscular a fecundou. A mitogênese teria sucedido à perda da língua comum a todos os humanos mas, ao mesmo tempo, representou a origem dos idiomas e dos povos. Ou seja: segundo o filósofo, nos falares diversificados e nas diferentes míticas persiste, embora de modo confuso e fragmentário, uma recordação da unidade humana perdida.

Na teoria de Schelling combinam-se, pois, olvido e lembrança na gênese das diferentes mitologias, em um processo que também acarretou a etnogênese e a variação idiomática (a propósito, ver SERRA, 2002, pp. 118-127). Sublinho o postulado da relação entre os surtos mitológicos e a nova manifestação / ocultação da linguagem.

Não cabe, nestas páginas, aprofundar o exame do "meta-mito" do filósofo. Reitero, porém, que essa fabulação teórica, eixo da arquitetura da obra mais intrigante de Schelling, postula uma relação crítica entre a revelação/ocultação da linguagem e o surto dos mitos. ${ }^{1}$

Passo agora ao discurso do teórico da antropologia estrutural.

A propósito da origem da linguagem, LéviStrauss fala de nascimento e aparição. Também se poderia falar em abertura de um horizonte, pois esse aparecimento implica a intuição de uma totalidade (o universo tornado significativo) que não se deixa alcançar quando assim se manifesta, antes permanece inatingível enquanto todo, muito embora sua intuição constitua uma condição de possibilidade das manifestações de sentido, logo também das conquistas de conhecimento.

É tempo de citar o trecho da famosa Introdução à obra de Marcel Mauss, em que o mestre da análise estrutural trata do problema:
Quaisquer que tenham sido o momento e as circunstâncias de seu aparecimento na escala da vida animal, a linguagem só pode ter nascido de uma vez. As coisas não puderam passar a significar progressivamente. Em seguida de uma transformação cujo estudo não compete às ciências sociais, mas à biologia e à psicologia, efetuou-se uma passagem de um estágio em que nada tinha para um outro em que tudo tinha sentido (...); esta mudança radical não tem contrapartida no domínio do conhecimento, que se elabora lenta e progressivamente. (LÉVI-STRAUSS, 1974, pp. 32-35)

Ou seja, como ele segue argumentando: no momento em que todo o universo tornou-se, de um só golpe, significativo, nem por isso se tornou melhor conhecido. Decorre desse postulado uma oposição entre o simbolismo - caracterizado pela descontinuidade - e o conhecimento - marcado pela continuidade - . Dá-se que "as duas categorias de significante e significado constituiram-se simultânea e solidariamente como dois blocos complementares". Mas o conhecimento progrediu muito devagar - constata o sábio. Ele então define o conhecimento como “o processo intelectual que permite identificar, uns por relação com os outros, certos aspectos do significante e certos aspectos do significado" e assim faculta "escolher, no conjunto do significante e no conjunto do significado, as partes que apresentam entre si as relações mais satisfatórias de conveniência mútua".

Pode-se aproximar essa definição levistraussiana de um modelo antigo: assim entendido, o processo que resulta em conhecer aparentemente corresponde ao que os gregos chamavam de symbállein. A ideia subjacente é a do sýmbolon. Admitindo-se essa aproximação, o exame da estrutura do sýmbolon pode esclarecer o que diz o antropólogo sobre significação e conhecimento.

Escrevi sýmbolon porque desejo referir-me ao que este termo significava originariamente. Convém recordar: no grego antigo, sýmbolon designava o conjunto e cada uma das metades de um objeto dividido em duas partes religáveis, passíveis de complementar-se exatamente, favorecendo um meio de identificação: o portador de um desses fragmentos, ao apresentá-lo, fazia-se reconhecer por quem detinha o outro.
1. Seria interessante analisálo comparando-o com o que dizem mitos de diferentes povos sobre uma original catástrofe da linguagem e suas consequências genesíacas... Mas isso é tema para um outro estudo. 
A ideia sobrevive em certos costumes contemporâneos. Ainda hoje é possível encontrar casais de namorados que deste modo manifestam (significam) sua ligação: cada membro do casal usa metade de uma moeda, ou medalha, num colar. Quem vê uma moça que assim se enfeita logo infere a existência de seu namorado. A informação está na ausência marcada no objeto visível em seu colo. A fratura chamativa sustenta a mensagem na moeda amorosa, no sýmbolon que o aparente e o inaparente constituem. 0 corte visível dá testemunho do todo sobre o qual incidiu, presentifica a cesura e a junção possivel; a correspondência do todo indiviso original com o conjunto das partes religadas (quando elas o são), portanto, de algo que pode fazer-se ver e algo que já não o pode, constitui outra dimensão desse pequeno, mas poderoso aparelho simbólico.

0 exemplo do casal (como o da "tessera hospitalis") remete ao pensamento de um par em que "peças" inteiriças se rearticulam diretamente; mas está claro que o mesmo esquema se aplica nos casos em que um objeto se divide em múltiplos fragmentos passíveis de religar-se. Torna-se, então, mais complexo o trabalho de achar os fragmentos que se combinam (num quebra-cabeças, por exemplo). Nesse caso, a conjectura (de conjicere, que equivale a symbállein) tem diante de si um campo mais vasto e mais sujeito a equívoco, visto que diferentes combinações entre pares de peças se afigurem possíveis, mas só uma delas se revele de fato adequada, conveniente. Seja como for, um quebra-cabeças apenas se mostra solúvel se desde o princípio o buscador tiver a certeza de que todas as peças pertencem a um todo que se fragmentou. Se não o percebe ou imagina, nada levará alguém (pessoa ou grupo) a fazer tais combinações.

Lévi-Strauss fala de significante e significado como (peças) complementares; fala de aspectos de um e de outro que podem ser colocados em correspondência (mais ou menos perfeita, mais ou menos adequada); fala de "partes que apresentam entre si as relações mais [ou menos] satisfatórias de conveniência mútua" (op. cit., ibidem). Também se refere a uma escolha entre essas partes, escolha que obviamente supõe algum tipo de conjetura [do lat. coniectura, que se reporta a conjicere]. Eis porque aproximo do paradigma do sýmbolon o discurso em que ele trata da linguagem e caracteriza o conhecimento no texto aqui considerado.

Nesse mesmo texto, ele dá curso a seu argumento com uma observação notável: a partir do pressuposto de que o universo "significou, desde o começo", tudo quanto "a humanidade poderia esperar conhecer a respeito dele", infere, com boa lógica, que decorre uma superabundância de significante com relação aos significados passiveis de corresponder-lhe: um excedente de significação ao dispor dos homens, "ração suplementar" de fato necessária "para que, no total, o significante disponível e o significado penetrado permaneçam entre si na relação de complementaridade que é a própria condição do exercício do pensamento simbólico" (idem, ibidem).

Ora, o surgimento da linguagem "nascida de vez", num natal de Palas, é ao mesmo tempo a aparição do mundo propriamente humano, inseparável dela. Mundo sem significação não é ainda o mundo de homens e mulheres, não comporta nossa humanidade. Lévi-Strauss o indica em um texto famoso sobre "Les mathématiques de l'homme", onde afirma que a linguagem não apenas implica a vida em sociedade; a rigor, ela a inaugura... "pois o que seria uma sociedade sem linguagem?".

Pois bem: o exercício da fala, que corporifica a linguagem verbal, dá-se em um jogo de interações, assenta em campo dialógico. Envolve e "realiza" a vida social no espaço de uma decisiva esfera de trocas. Assim sendo, “o aparecimento da linguagem", nos termos em que Lévi-Strauss 0 caracterizou (como algo ocorrido "de uma vez") não pode corresponder pura e simplesmente à gênese de um primeiro idioma, de uma língua primordial. Essa primeira língua humana, como todas os outras, há de ter surgido em um contexto cooperativo. A rigor, uma língua é uma cooperativa... E se houve uma originária (língua primitiva de que as outras derivariam), ela há de ter tido uma construção dialógica, como as demais. Idioma nenhum surge pronto, de uma só vez. Segundo penso, quando fala na aparição da linguagem Lévi-Strauss se refere ao desvelar-se da significatividade, que possibilita a floração (a construção) das línguas. Isso equivale, 
creio eu, ao desabrochar do que Chomsky chamou de competência linguística.

0 revelar-se da significância, a percepção do existente como significativo, é, pois, o fenômeno originário, uma espécie de salto para nova dimensão. Evidentemente, o que acontece "de uma vez", de salto e sem mudança, em um indeterminado ponto de origem, não tem história. 0 sucesso que Lévi-Strauss assim caracteriza coloca-se, pois, além da história, fora do alcance das ciências da sociedade, em um domínio, como ele diz, que só a biólogos e psicólogos compete explorar. Por outro lado, línguas evidentemente têm história, são históricas. Da primeira à última, pode-se supor - ainda que a(s) história(s) da(s) mais antiga(s) e da(s) derradeira(s) por força nos escapem. Em cada idioma, a designação é sempre work in progress. Se acatamos o pressuposto de que o universo se tornou significativo de uma só vez, nem por isso podemos concluir que simultaneamente a essa irrupção do sentido chegou-se a designar imediatamente cada coisa ou fenômeno no imenso campo assim descortinado.

Designar não equivale, necessariamente, a conhecer. Quando um navegador antigo assinala em um mapa uma terra incognita, entende e afirma que ainda não a conhece, embora pretenda traçar-lhe o contorno. A linguagem também nos provê meios de indicar terra incognita.

Em todo o caso, a designação supõe descoberta (e invenção) de coisas diferentes que a priori se considera dotadas de sentido.

Não se pode considerar conhecido tudo o que foi designado, como Lévi-Strauss indica; mas, por outro lado, nem tudo que aparece como capaz de significar chega a designar-se. Por vezes, damos um crédito significativo a coisas que mal percebemos, atribuímos a fenômenos para nós obscuros um sentido que não advertimos. 0 sentido que assim intuímos ultrapassa o raio da designação que "individualiza" o ente ou acontecimento em tela.

A reflexão de Lévi-Strauss nos dá a perceber também outra coisa: no seu despontar, a linguagem traz consigo, imediatamente, o sentimento de uma totalidade necessária (já que "de relance" tudo significa); mas essa totalidade permanece virtual, sempre diferida, projetada mais além por uma antecipação nunca inteiramente satisfeita.

Por fim, na proposição levistraussiana o conhecimento parece ser caracterizado como uma adaequatio em que o significante cifra a intelecção quando se encontra "de maneira conveniente" com o significado. A meu ver, a cada encontro desses o horizonte recua e o que está por conhecer projeta sobre a nova clareira uma sombra que o sentimento do inapreensível estende.

Há que reconhecer uma precedência (e até um privilégio) do pensamento simbólico, se é certo que este corresponde ao despontar da linguagem - portanto à epifania do mundo enquanto mundo (campo aberto para a significação). Esta correspondência não se limita, por certo, à circunstância de um "acontecimento" significativo preso no passado: o "acontecimento da significação" é mais do que um sucesso isolado; há de permanecer ativo (significativo) em todo o tempo. Do despontar sem começo que é a aparição do mundo espraiado na linguagem, a poesia continua a dar testemunho: ela é que efetivamente faz falar a linguagem: deixa que ela fale e a isso a convida. É então que ela evoca seu próprio limite, acusa o inefável.

A configuração básica dos enigmas, ou, pelo menos, de um grande número deles, corresponde também à do sýmbolon (SERRA, 2006). É fácil advertir que a estrutura do sýmbolon compõe um arranjo analógico. Imaginemos um rito hospedal em que, nas despedidas, o anfitrião entrega ao hóspede metade de um prato de louça que, para isso, quebrou, ficando com a outra: esse pequeno rito origina um sýmbolon. Chamando-se os fragmentos obtidos na partilha de $\mathrm{A}$ e $B$ e seus detentores de $C$ e $D$, respectivamente, é claro que esses elementos podem ser correlacionados no esquema de uma proporção, ou, em grego de uma analogia. A evidente pertinência dos fragmentos a um todo que podem recompor indica a pertinência de seus portadores a um conjunto que assim definem. A corresponde a C, seu portador, assim como B a D. Ou seja, A: C :: B: D. Maranda (1971) mostrou que uma adivinha - um enigma típico - vem a ser uma 
3. Cf. Lévi-Strauss 1976, p. 50: “A proibição do incesto está, ao mesmo tempo, no limiar da cultura, na cultura, e, em certo sentido (...) é a própria cultura)."

4. Os etólogos já mostraram que a evitação de inbreeding acontece na natureza entre outros nimais superiores. Na perspectiva

levistraussiana, o interdito do incesto parece que vai além dess evitação: pressupõe o fluxo de trocas simbólicas nas sociedade já humanas, onde toma forma de instituição. Na perspectiva da etologia, é legítimo falar em sociedades e mesmo em culturas de animais não humanos. Isto se torna possível quando se define cultura do modo mais simples, como "comportamento aprendido". Lévi-Strauss, porém, quando fala em sociedades, refere-se somente

às humanas, que destaca em função de uma característica distintiva: é a presença da linguagem que as caracteriza e singulariza.

5. 0 filósofo Floyd Merrel, que generosamente leu este artigo em primeira mão, observou-me, a propósito, que se a relação de significante e significado deve ser efetivamente pensada como complementar, impõe-se a ultrapassagem do binarismo atreito à lógica bivalente, de terceiro excluído, pois a complementaridade em sentido próprio envolve um compromisso dos termos opostos, transcendendo a simples correlação opositiva: implica o surgimento de um "terceiro incluído". Assim é que os símbolos de Peirce funcionam de modo complementar, de fato, pois são da categoria da Terceiridade.

6. Recorro aqui à tese de Kierkgaard (2006, p.49) sobre "0 conceito de ironia". No trecho

a que me reporto, o filósofo

discorre sobre a concepção do amor exposta no diálogo platônico

0 Banquete, com o propósito

de mostrar 0 alcance da ironia

socrática (da ironia encarnada por Sócrates nesse texto famoso)

e passa a considerar, por meio de breve (mas riquíssima) analogia,

o conhecimento: “0 abstrato de Sócrates é uma designação completamente sem conteúdo. Ele parte do concreto e chega ao que há de mais abstrato e lá onde a investigação deveria começar, ela termina. 0 resultado a que ele chega é propriamente a determinação indeterminada questão que contém a resposta, todavia, velada. Pergunta e resposta devem combinar-se para que o problema se resolva, mas para isso é preciso encontrar a imagem não expressa que corresponde à expressa na questão. Trata-se de um jogo que se concretiza na arena do diálogo, iniciado por uma demanda, um repto (SERRA, 2002, p. 41 e seguintes). Quem faz o repto apresenta uma "peça" de um conjunto analógico, e a conclusão positiva (a decifração) se dá quando o desafiado encontra a quem, de algum modo, the corresponde, que pode combinar-se com ela. Se tem êxito, as peças se encaixam, "casam-se" uma com a outra. Claro, para tanto, é preciso fazer conjeturas. 0 grau de complexidade do enigma será maior se diferentes "encaixes" forem possíveis, mas um apenas corresponda ao requerido. Tudo começa com um repto, contido numa indagação. E geralmente o repto se faz de modo a cercar o interrogado entre difíceis alternativas: "decifra-me ou devoro-te", "responda ou pague a prenda".

Como lembro no estudo citado (p. 44), em muitas sociedades o jogo das adivinhas tem a ver com ritos nupciais, tem lugar privilegiado em bodas ou em suas preliminares. Frequentemente, opõe os casadouros dos dois sexos e integra a prática de "fazer a corte". Concerne, então, ao conúbio, que os gregos também chamavam de symbolé.

$\mathrm{Na}$ Anthropologie Structurale (LÉVI-STRAUSS, 1973, p. 34), a noção de enigma é dada como chave para o entendimento da natureza da conduta incestuosa. Aí também se afirma que o interdito do incesto deflagra a cultura, corresponde à cultura. ${ }^{3}$ Ora, segundo acima já lembramos, Lévi-Strauss acredita que a cultura começa com a linguagem, que sem linguagem não existe sociedade humana. Logo, para ele a aparição da linguagem e o interdito de incesto figuram no mesmo limiar, inaugurando a cultura.

Já vimos como ele relaciona de modo original simbolismo e conhecimento quando discorre sobre a linguagem com emprego de uma metáfora que evoca uma certa forma simbólica: justamente a forma do sýmbolon, estrutura a que também se podem reportar enigmas. Mais adiante veremos que ele confere ao enigma importância decisiva no contexto de uma abordagem do universo da mitologia. Mas antes disso creio que cabe mais um breve comentário sobre sua visão da linguagem e do conhecimento.

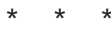

No ponto de partida da reflexão de Lévi-Strauss está o modelo saussureano da significação. Creio, porém, que é preciso ir além do par significante/significado: ultrapassá-lo, como propunha Peirce, através do apelo à noção de interpretante ${ }^{5}$. Com isso, torna-se mais fácil volver os olhos para o limbo promissor da significação que germina e acena para a consciência, o limiar onde o sentido apenas se insinua e já transborda, avança, se move e transforma. 0 interpretante promove um deslocamento contínuo que revela a natureza processual da significação. Essa trajetória se torna ainda mais complexa quando se trata de uma produção de conhecimento.

Talvez se possa esclarecer o que ficou dito, evocando Kierkegaard, com uma pequena inversão na ordem de uma frase em que ele tangencia este ponto: recordando, com o filósofo, que se 0 conhecimento também é posse, por outro lado é [movimento (constante) de] apropriação... portanto é sempre busca, e tem a marcá-lo sempre, de modo indeclinável, um princípio negativo. ${ }^{6}$ A linguagem traz consigo um imperativo de ordenação. Mas a ordem que ela comporta (ou anseia) não se impõe com a mesma imediatez da intuição primeira da significatividade do mundo. Afirma-se em um processo em que as resistências se fazem sentir de modo constante. Confrontando a desordem (o não ordenado) das aparências sobre as quais trabalha, a linguagem o faz sentir. Nesse afã, a limitação do dizível é tornada evidente pelo progresso do dizer, nunca saciado em sua gana.

A pressão do inefável que a linguagem aponta soma-se à superabundância de significante a que Lévi-Strauss se refere para produzir um sentimento abissal de insuficiência que acompanha todo triunfo no dizer e no saber - uma insatisfação cujo efeito positivo é espicaçar nossa criatividade (linguística, poética, científica). 
Segundo creio, é lícito presumir que o universo significou, desde o princípio, mais do que a humanidade pudera (e pode) esperar conhecer-lhe. Nos discursos míticos, a confiança, no sentido do mundo, geralmente ultrapassa a esperança de sua compreensão pelos humanos. 0 mesmo thaûma agita a filosofia, assim como a ciência. Também por isso - ou seja, em virtude do invencível espanto do puro existir, do transbordamento sem explicação do ignoto que reclama sentido (e o solicita mesmo quando se afigura inexplicável, inapreensível) - há um movimento incessante no espaço da significação: uma pulsação que toca o nonsense no derramamento de possibilidades a eletrizar a distância que sempre remanesce entre o percebido e o assinalado, assim como entre o designado e o conhecido, no seio claro-escuro da linguagem.

Indica-o Giorgio Agamben quando acusa "o fato de que uma palavra tem sempre mais sentido de quanto possa em ato denotar" e "entre sentido e denotação existe uma sobra insuturável" (2007, p. 32). Sublinho o que ele acrescenta: “... é justamente esta sobra que está em questão tanto na teoria levistraussiana da excedência do significante em relação ao significado (...) quanto na doutrina benvenistiana da oposição irredutível entre o semiótico e o semântico" (idem). 0 pensamento se empobrece quando subestima essa fenda caótica, quando tenta ignorá-la... ${ }^{7}$

0 trabalho simbólico da linguagem não fica cingido às demandas do que é (ou se presume) dado, pois ela também reflete, além disso, não só o jogo da fantasia como o conato do dever ser. Basta reconhecê-lo para dar-se conta de que aí pulsa, transfigurada, a força do desejo. Eis onde procura afirmar-se a ordo amoris de que falava M. Scheller: o campo dos valores. Eles não requerem só constatação. Exigem um ato de vontade, movimento indispensável para assumi-los ou denegá-los.

De qualquer modo, uma coisa é certa: a linguagem se beneficia do excesso que a faz transbordar, que, por vezes, a impele para além do campo lógico. E o benefício que daí tira recai sobre o próprio conhecimento - mas a preço de uma exposição ao erro e ao equívoco.
Se a linguagem verbal tem um privilégio inegável por mostrar-se investida tanto de criatividade (no sentido chomskyano do termo) como de secundariedade - fatores que a erigem em um poderoso suporte da consciência -, de fato ela não domina o campo da significação de um modo exclusivo. A seu lado, há outras formas de expressão que the são irredutíveis, mas relevam da mesma competência simbólica. ${ }^{8}$ As decalagens verificáveis entre esses códigos acusam um novo transbordamento da significação. A força com que diferentes códigos não verbais transmitem sentido leva a imaginar uma articulação de todos eles - incluindo e transcendendo o domínio do verbo. No horizonte da mítica dos gregos, a figura divina de Mnemósine corresponde a essa imaginação.

Em ponto menor, a irredutibilidade dos diversos códigos expressivos tem um correspondente no seio do verbo, onde remete à heteroglossia: se as diferentes línguas são reciprocamente interpretáveis, em grande medida intertradutíveis, nem por isso é menos verdadeiro que elas nunca se equivalem de todo, nunca são, de fato, plenamente comensuráveis. ${ }^{9}$

Lévi-Strauss caracterizou a música como simultaneamente inteligível e intraduzivel. De fato, por isso mesmo, ela é percebida - em diferentes culturas - como uma linguagem superior, que permite a ultrapassagem das barreiras idiomáticas. ${ }^{10}$ Ora, já para os gregos "música" é o fazer das Musas. Isso inclui todas as linguagens em que o mundo pode tornar-se manifesto... "em virtude de Mnemósine", para dizê-lo em termos helênicos, ou melhor, com - vocabulário mítico dos helenos. Outro nome possível para esse fazer das Musas é poesia. Hoje o preferimos... Os gregos falariam antes de mousiké.

Evidentemente, a mousiké não se reduz ao que chamamos de música. Todavia, é certo que a compreende. Arrisco-me a conjeturar que o sentimento do silêncio é conatural da linguagem, nasce com ela - e daí é que brota a musicalidade humana. Pois o silêncio não se reduz a ausência de som, não equivale a efeito da surdez. De sua criação só é capaz quem experimenta o desprendimento do sentido, que o afirma na ultrapassagem da simples referência.

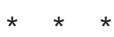

do puro ser: 0 amor é, pois, 0 adendo, que é nostalgia, busca, não é nenhuma determinação, dado que isto é meramente uma relação com uma coisa que não é dada. Do mesmo modo, poder-se-ia reportar também o conhecimento a um conceito completamente negativo, determinando-o como apropriação, aquisição, pois esta é, aliás, uma das relações do conhecimento com o conhecido; mas por outro lado o conhecimento também é posse". Cabe talvez acrescentar que esta posse é sempre efêmera na medida em que exige o salto para adiante, um desprendimento rumo à falta que necessariamente leva a advertir.

7. A propósito do nonsense, ver Dorfles, 1988.

8. Ou "competência comunicativa", como a entende Hymes (1974).

9. A propósito, ver ainda Dorfles, 1988: 25: “... todas as tentativas de fazer ligar entre si termos na aparência homólogos ou análogos, e apesar de denotativamente

idênticos, demonstram claramente quantos 'hiatos semânticos' existem entre os vocábulos das diferentes línguas". Recorde-se também a tese de Benjamin, para quem o intradutível é o ponto de partida de toda tradução...

10. Assim ela é pensada no mundo xinguano, por exemplo... A propósito, ver Menezes Bastos, 1978. Para os xinguanos (se bem entendo a tese de Bastos) a música realiza como que um Pentecostes. Entre os gregos, - Hino Homérico a Apolo Délio sugere uma superação ritual das diferenças idiomáticas, prodigiosamente alcançada pelo canto sagrado das donzelas délias: “De todas as gentes as línguas com seus sotaques/ Elas sabem imitar: qualquer que ele mesmo fala / Creria: tão clara a todos a sua bela cantiga!" 
Para submeter-se à análise estrutural, logo de início os mitos têm de ser "descarnados", reduzidos a esqueletos narrativos, a esquemas muito simplificados em que perdem algumas de suas características mais expressivas. É inegável que, com isso, ganha-se muita coisa: desde logo, um meio de desvendar relações que de outro modo não se explicitariam no corpo da narrativa. Logra-se ainda a possibilidade de tornar os mitos interpretáveis uns pelos outros em uma escala espantosamente ampla. A própria descontextualização que ocorre no processo revela-se positiva na medida em que permite transcender o entorno imediato e descobrir relações significativas muito além, ou seja, em outros contextos, a que uma visão pontual não permitiria acesso. Mas, nessa ótica, não se dá sempre a mesma atenção aos usos nativos dos mitos, aos desempenhos em que eles se fazem presentes, a seus veículos, aos cenários em que eles se exibem, às formas que os transmitem nos meios onde vivem. A análise estrutural revela uma das dimensões da mítica. Convém sempre lembrar que há outras. Em todo o caso, aqui tratarei apenas desse vasto espaço que Lévi-Strauss faz descortinar.

11. Nessa altura, Lévi-Strauss parece ceder a um mito positivista

(a Lei dos Três Estados) com um certo tempero de logocentrismo ( eurocentrismo) helenófilo.

12. Na mesma entrevista, p. 180

De acordo com o mestre do estruturalismo, os mitos procedem sempre de um mesmo modo, face a contradições que, não chegando nunca a se resolverem, transferem-se interminavelmente de um a outro plano, por meio de um jogo de homologias. Isto sugere uma deficiência apenas superada com o advento do pensamento filosófico-científico, algo como uma epifania decisiva do Logos (sucesso este que, segundo Lévi-Strauss, ocorreu em um tempo/lugar bem definido: a Grécia Antiga). ${ }^{11}$ Mas o que mostra a fórmula canônica do mito é um desenvolvimento baseado numa torção do aparelho analógico, torção capaz de fazer da contradição (via inversão e conversão) uma passagem para outro desenvolvimento equiparável. 0 que sempre resulta é um progresso da alcance cada vez maior às correspondências. Para mostrá-lo, vale a pena evocar explicações dadas por Lévi-Strauss em uma entrevista famosa:

É característica do mito diante de um problema pensá-lo como homólogo a outros problemas que surgem em outros planos: cosmológico, físico, moral, social etc. E analisar todo o conjunto. (...) 0 que o mito diz numa linguagem que parece apropriada a um domínio estende-se a todos os domínios em que poderia surgir um problema do mesmo tipo formal. (LÉVI-STRAUSS; ÉRIBON, 1990, p.179):

Ou seja: o pensamento mítico, confrontado com um problema particular, coloca-o em paralelo com outros, "sem jamais resolver problema algum". ${ }^{12}$ Sucede uma espécie de engano consolador, por assim dizer: a similitude dos problemas "dá a ilusão de que podemos resolvê-los, a partir do momento em que se toma consciência de que a dificuldade notada num caso não existe, ou não no mesmo ponto, em outros".

A rigor, não é necessariamente um procedimento ilusório mostrar que algo tido como problemático em uma determinada situação não apresenta o mesmo teor de dificuldade em outras, nem sequer constitui problema. Pode até ser um modo de enhomologia. A contradição que, em princípio, se põe como problema, acaba sendo o meio pelo qual um grande encadeamento analógico se estende indefinidamente. Ela se torna o motor de uma différance que alonga o campo das relações e assim dá um caminhar solução. Se for bem conduzido o exame, talvez se possa, em tese, isolar o que efetivamente constitui a crux do problema. Mas Lévi-Strauss presume que, no horizonte do mito, as coisas não se passam deste modo. Ele acusa uma deficiência, fala de uma ilusão. Que até parece um encantamento... Cabe a pergunta: como pode ser que, mesmo portando essa deficiência, mesmo viciado por sua manha de iludir(-se), o pensamento mítico tenha sido capaz de incorporar, preservar e transmitir conhecimentos efetivos, que o próprio Lévi-Strauss considera válidos, científicos avant la lettre? Ele não o explica. Mas admite que a estrutura mítica pode dar abrigo a conhecimento "propriamente dito." e afirma que os mitos propiciam indiretamente um (re)conhecimento de grande importância: revelam o funcionamento da mente humana. Essa revelação eles a fazem a quem os analisa. Não aportam saber dessa ordem a seus usuários diretos, a quem os produz e comunga. De acordo com o mestre da 
análise estrutural, o significado que um mito pode aportar a quem o narra ou escuta em um dado momento, em circunstâncias determinadas, "só existe com relação a outros significados" que ele "pode oferecer a outros narradores e ouvintes, em outra circunstância e num outro momento". (LÉVI-STRAUSS \& ÉRIBON, 1990, p. 182). Através de longa viagem comparativa é que o mitólogo ganha acesso a esse remoto significado.

Cabe a dúvida: quem se vale de mitos nas condições de emprego que eles normalmente têm onde circulam, estará condenado a só obter deles a mera ilusão, o sedativo engano? É certo que, no singular, o mito não ilumina? Quem ouve o canto do aedo e com ele se encanta, nada descobre de novo no mundo?

Parece temerário afirmá-lo. Se a análise de um conjunto de histórias tradicionais do tipo das classificadas como "míticas" manifesta uma estrutura de inteligibilidade e se essa estrutura só assim se revela ao estudioso, não decorre disso, necessariamente, que sua singularidade nada aporte; não se deduz per force que o mito nada diga do mundo no espaço em que desponta.

Lévi-Strauss reconheceu o potencial cognitivo de mitos singulares pelo menos em uma oportunidade: em um estudo (2004a:40-2) publicado pela primeira vez em 1993 em que aproximou muito sua teoria do pensamento de Vico. Mas aí o conhecimento que o mito proporcionaria é, de certo modo, "diferido", posto como uma virtualidade capaz de realizar-se - ou não - no contexto de experimentos científicos (posteriores à mitopéia, evidentemente) nos quais pode verificar-se válido o ensaio lógico da imaginação mítica (para o dizer assim). ${ }^{13}$ De um modo geral, Lévi-Strauss está convicto de que os mitos são reveladores apenas no que toca a l'esprit humain; falham no que respeita ao conhecimento efetivo do universo. Neste caso, o aparelho mostra logo sua fragilidade. Onde está ela?

Uma coisa ele deixa claro: não se trata de uma insuficiência intelectual dos usuários da mítica, pois os mitos transparecem uma grande capacidade de abstração, desfrutada por quem os cria e acolhe.

Recorde-se, a propósito, um pronunciamento famoso do autor de Du miel aux cendres, contido no derradeiro capítulo deste livro, no trecho em que ele discorre sobre "les instruments de tenèbre" e trata de uma mudança relativa ao percurso encetado na primeira fase do seu grande projeto das Mythologiques. Na etapa inicial (em Le Cru et le Cuît), a fim de construir o sistema dos mitos de cozinha sul-ameríndios, ele trabalha com oposições entre termos (quase todos) designativos de qualidades sensíveis (tais como cru e cozido, fresco e podre, seco e úmido etc.). Na etapa seguinte, eis que surgiram termos novos, ainda em pares de opostos, mas de outra natureza, pois já não concerniam a uma lógica das qualidades e sim a uma lógica das formas: termos como vazio e cheio, continente e conteúdo, interno e externo, incluído e excluído. ${ }^{14}$ Ainda neste caso, os mitos procedem traçando correspondências entre vários códigos, de forma simultânea. Vêm então a assumir uma posição axial, no sistema, certas representações sensíveis que se correlacionam com uma pluralidade de funções feitas homólogas, de modo que se torna possivel transitar de uma a outra em um percurso já marcado pela abstração. 0 progresso definitivo, o grande salto rumo à ordem dos conceitos, afirma Lévi-Strauss, verificou-se uma vez na história, "aux frontières de la pensée grecque, là où la mythologie se désiste en faveur d'une philosophie qui émerge comme condition préalable de la pensée scientifique.» ${ }^{15}$

Por que só aí, por que só então? Na citada entrevista a Didier Éribon, Lévi-Strauss confessou ( $p$. 174): "Nada sei a este respeito". Mas no mesmo diálogo, pouco adiante, ele fez uma observação que corresponde a uma explicação da precariedade da elaboração mítica: lembrou que o mito atua "por meio de imagens e acontecimentos, que são objetos rústicos" (p. 183).

Ora, talvez resida justamente nisso um fator decisivo do inegável poder de sedução dos mitos ${ }^{16}$ : a razão pela qual não conseguimos deixá-los de lado, antes seguimos recorrendo a eles e fabulando sempre: dá-se que efetivamente todos nós vivemos em um mundo de imagens e acontecimentos. Mais ainda: a rigor, nós "acontecemos", somos nosso acontecer. E nos embebemos de imagens, mobilizadas nas narrativas em que nos apresentamos não só aos outros como a nós mesmos, ao construir (e
13. Curiosamente, entre os exemplos que dá no dito estudo ele evoca, também, reflexões de filósofos, dos primeiros pensadores gregos. Apela até a uma antiga anedota sobre Demócrito.

14. 0 terceiro momento se expõe em L'Origine des Manières de Table, quando se descortina nos mitos ameríndios uma lógica de intervalos temporais, baseada em oposições do tipo "longo x curto" "cíclico x serial".

15. A passagem das Mythologiques que citei acima sempre me faz lembrar a maneira como Nietzsche caracteriza o procedimento filosófico de Parmênides (cf. Nietzsche, 2008:75-6): "Parmênides... comparou as qualidades entre si e acreditou ter descoberto que elas não eram todas semelhantes, mas antes que tinham de ser ordenadas segundo duas rubricas. Quando comparou, por exemplo, luz e escuridão, então esta segunda qualidade era evidentemente apenas a negação da primeira; e assim foi que ele distinguiu qualidades positivas e negativas, esforçando-se seriamente para reencontrar e marcar esta oposição básica em todo o âmbito da natureza. Seu método, aqui, era o seguinte: ele tomava um par de opostos como, por exemplo, leve e pesado, fino e espesso, ativo e passivo, e mantinha-os à luz daquela oposição exemplar entre luz e escuridão; aquilo que correspondia à luz era o positivo, aquilo que correspondia à escuridão, a propriedade negativa. Se tomava, digamos, o pesado e 0 leve, então o leve recaía sobre o lado da luz, ao passo que o pesado sobre o lado da escuridão; e desse modo o pesado era-lhe apenas negação do leve, mas este, por seu turno, era-lhe uma propriedade positiva. Desse método decorre já, uma obstinada aptidão para o pensamento lógico-abstrato, impermeável às influências dos sentidos..."

16. Eudoro de Sousa costumava dizer que em nossa civilização somos quiçá mais "vulneráveis" aos mitos, justamente porque pensamos estar livres deles. 
ter construídas) nossas pessoas. Todavia, é certo que a ciência costuma levar-nos em outra direção: a objetificações que chegam, como dizia Bachelard, ao ultra-objeto, avesso e oposto à imagem. ${ }^{17}$

Dito isso, volto agora a outro ponto que já

17. 0 exemplo típico de ultraobjeto que Bachelard aponta, evocando Eddington, é o átomo da física moderna (BACHELARD, 1972, pp.194-6). Destaco o que ele diz neste ensaio à p. $195 \mathrm{e}$ na seguinte: “Tal como surge na microfísica contemporânea, o átomo é o tipo perfeito do ultraobjeto. Nas suas relações com imagem, o ultra-objeto é muito exatamente a não-imagem.

18. É claro que antinomias também podem ser positivamente consideradas no horizont das lógicas "dialéticas" ou "paraconsistentes".

destaquei. Parece lógico pressupor que, quando expomos contradições, é sempre para superá-las, resolvê-las. No entanto, recorde-se a tese levistraussiana: o mito as confronta sem as resolver; antes as desloca de modo constante. Será que só na mítica isto acontece?$$
\text { * } \quad \text { * }
$$

Claro, frequentemente homens e mulheres se defrontam com situações críticas em que constatam, põem para si mesmos, problemas sem solução. É comum que tentem esquivá-los de algum jeito. 0 discurso que efetivamente problematiza procede à busca direta da solução, sem desvios. Pode ser que esta não seja lograda. Muitas vezes não o é. Porém não se contorna a questão. Avalia-se, ou tenta-se avaliar o seu alcance, sua "acessibilidade". É este o modus agendi do cálculo, da ciência. Aí, o problema considerado insolúvel tem de ser declarado tal, após sucessivas verificações. Na melhor das hipóteses, reconhece-se, então, que os recursos teóricos ou técnicos disponíveis de momento não dão conta dele; resta a esperança de que, no futuro, novas descobertas possibilitem resolvê-lo. Ou senão - na hipótese pior - reconhece-se uma aporia ("invicta", ou mesmo "invencível"). Quando resultados contraditórios a que se chega racionalmente afiguram-se inelutáveis, denunciam-se antinomias ("conflitos entre as leis da razão pura", para falar como Kant). Demonstrar antinomias, fazê-las reconhecer, vem a ser um ganho de conhecimento - um ganho que, na perspectiva kantiana, se pode chamar de crítico, pois implica em reconhecimento dos limites da razão, "freios" da metafísica. ${ }^{18}$ Reconhecer oposições fundamentais em nossa vida é um passo essencial para o aprofundamento dos problemas nos domínios da Filosofia, como Max Scheler repetidamente mostrou.

Já Aristóteles (Met. 995a-b) assinalava o encontro da contradição como o ponto de partida da investigação filosófica: esta percorre a diaporia, ou seja, refaz o desenho de vários caminhos, a rigor divergentes, quando ensaia definir seu próprio rumo (como se vê, por exemplo na Metafísica, na maneira como o filósofo aborda o pensamento dos seus predecessores a propósito de cada assunto, explorando o contraditório). Nesse processo, o confronto da aporia é reconhecido como o primeiro momento de toda a reflexão filosófica. A rigor, para Aristóteles, é o que a faz deflagrar-se, por efeito do thaumázein. Ora, segundo a conhecida declaração do Estagirita (Met. 988b), esse "espanto" é também o ponto de partida da mítica (da filomitia).

Fala-se de aporia quando o processo de investigação resulta frustrado, ou seja, quando no termo "não se encontra saída" para o problema. Chamo aqui a atenção para o processo em si mesmo, pois quero apontar para sua característica mais decisiva no campo filosófico-científico: a explicitação das questões. É ela que abre caminho à investigação sistemática e metódica.

Nos textos citados em que caracteriza a mitologia, Lévi-Strauss repete por várias vezes a palavra problema. Parece claro que então ele emprega este termo em seu sentido mais simples: o de "dificuldade a resolver". Mas o sentido de problema que acabou sendo determinante na história da ciência e da filosofia foi consagrado por Aristóteles (ou melhor, pelos aristotélicos) graças, principalmente, à obra famosa chamada Problemata, que encerra dissertações sobre vários assuntos, estruturadas sob a forma de perguntas e respostas. Um dos significados do termo grego próblema é "tarefa proposta (a/por alguém)". Neste caso, a proposição (no sentido ativo do termo: a colocação da proposta), toma a forma de uma questão explícita a ser examinada sistematicamente, o que exige sua exposição e sua apreciação em um arrazoado.

Nos mitos, é raro que figurem questões explícitas (já se disse que mitos são respostas a perguntas de ninguém) e mais raro ainda é que elas se enunciem de modo a ser examinadas em arrazoados de corte analítico. Falta-lhes, aí, a problematização, tal como a entendem os cientistas e filósofos. Todavia, é bem certo que o discurso dos mitos envolve o enfrentamento de dificuldades desafiadoras para a inteligência - e que neles se experimenta o pungir de contradições. 
Em um espaço vizinho ao mito - a tragédia, que de mitos se nutre - são expostas dramaticamente contradições irresistiveis, insolúveis. No entanto, esta ausência de solução não diminui, de modo algum, o alcance do discurso trágico. A tragédia tem força esclarecedora: é mestra de uma inegável sabedoria.

Nem todo problema constitui enigma, porém é certo que entre problema e enigma há parentesco e vizinhança. Ocupam ambos territórios acidentados, multiformes, cheio de variações. Em particular, há muitos tipos de enigmas, famílias diversas. A uma dessas famílias pertencem os oráculos, as sentenças oraculares. E se engimas podem ser isolados, também podem formar cadeia. É longa a cadeia enigmática que envolve Édipo, por exemplo. Enigmas tendem para a aporia.

Como diz Charles-Henry Pradelles de Latour (2004, p. 182), Lévi-Strauss adota a definição aristotélica de enigma, que, de acordo com o Estagirita (Poética, 1458-25), consiste em combinar termos inconciliáveis. Na Anthropologie Structurale, ele fala que o enigma equivale a uma pergunta à qual se presume não haver resposta (pois a resposta, subentende ele, levaria ao choque dos opostos, dos termos incompatíveis).

Notáveis enredos trágicos envolvem enigmas ou discursos enigmáticos, abordam-nos e tratam deles expressamente. É o que acontece, por exemplo, no Macbeth de Shakespeare. Mais claramente ainda, é o caso do drama sofocleano Rei Édipo. Em ambas as tragédias, o enigma se liga a um contexto de profecias, de enunciados fatais. No caso de Macbeth, a ligação é imediata: a fala truncada das bruxas que levam a confundir o possivel e o impossivel fascina o herói e o arrasta para situações que desdobram seu efeito, sempre intrigando. 0 discurso enigmático configura 0 enunciado de sucessivas predições que atraem e compelem. 0 enigma que elas encerram cumpre-se, em vez de resolver-se: não é decifrado senão ao realizar-se - e esta realização elimina o pretenso decifrador, que em outro momento se empenha na realização do predito.

No caso de Édipo, a ligação é dupla, visto como o enigma passa por transformações. Primeiro se embute no oráculo; mas é de novo apresentado, sob outra forma, em um episódio que figura uma inversão do campo oracular. Cifra-se, nesse momento, numa questão diretamente posta ao herói: apresenta-se-lhe no corpo de um problema, com a forma de uma pergunta-desafio, (pro)posta com uma demanda explícita de solução. Tomando ciência do problema, o príncipe o "resolve"... Mas a solução o envolve na trama a que ele pretendia esquivar-se, confronta-o com o destino enigmático que 0 dominará. 0 decifrador, por fim, vai reconhecer em si mesmo a estranha cifra, encontrar em sua vida o enigma encarnado, portanto ineludível - o que é todo o contrário de uma verdadeira solução.

Esta lembrança não é sem propósito. Lévi-Strauss, certa feita, propôs classificar todos os mitos do mundo em duas classes representadas por casos exemplares de enredos míticos que lidam com enigmas. Isto equivale, claro está, a reportar a totalidade da mitologia ao campo enigmático.

Um enigma típico envolve a injunção de reunir pergunta e resposta suplantando dificuldades numa procura sujeita a desencontros fatais, numa operação de "custo" lógico elevado. Sua exigência, muitas vezes, devém a condição de franquia de uma possibilidade encarecida que implica a decisão de uma alternativa, clara ou velada. Por outras palavras, nas narrativas tradicionais o enigma típico tem também um "custo" prático: envolve a iminência de um impasse e encerra o confronto direto de uma situação contraditória que afeta a vida do interrogado. É evidente que isto se verifica no mito de Édipo, assim como na gesta de Percival. Segundo Lévi-Strauss (1976: I: 11-40), os mitos todos seriam quer edipianos, quer percivalianos.

É conhecido o argumento, mas convém recordar. Em uma passagem decisiva do romance de Percival, o herói, no castelo do rei Amfortas, não se atreve a indagar a quem serve a taça esplêndida que vê deslocar-se sozinha a sua frente. Assim ele perde a oportunidade de romper o encantamento opressor do rei enfermo e da terra gasta. Percival, o casto, deixa de fazer uma pergunta - e porque assim descura a resposta disponível, iminente, deixa de obter um grande sucesso. Já Édipo, o incestuoso, faz reunir-se uma resposta inesperada com a pergunta 
enigmática: no seu caso (cf. ibidem, p. 31), “a união audaciosa das palavras mascaradas", tal como "a de consanguíneos dissimulados" leva à ruína, "gera o apodrecimento e a fermentação". Provoca a peste tebana... Ou seja, ainda de acordo com a tese levistraussiana, os mitos edipianos têm a ver com "um inverno sem fim" (que o herói revoga ao decifrar o enigma) enquanto o problema a ser resolvido no ciclo do Graal é o do "gaste pays", do verão revogado. 0 ponto chave de todas essas correlações estaria numa correspondência básica: a castidade (estéril) de Percival está para a "resposta sem pergunta" assim como o incesto (corrupto) de Édipo estaria para a "pergunta sem resposta" - uma simetria que, em outra oportunidade, Lévi-Strauss (1984, pp. 129-137) traduziu em termos da oposição entre o problema da "comunicação interrompida" (Percival) versus o problema da "comunicação excessiva" (Édipo).

Sucede que as situações confrontadas foram um tanto simplificadas. 0 drama de Édipo é muito mais complexo. Na história do herói de Tebas verificam-se desencontros de pergunta e resposta (na consulta ao oráculo); há comunicação excessiva e insuficiente; o herói passa de contestador a indagador, de decifrador a enigma, e vem a ser, de um modo simultâneo, tanto o inquiridor como o objeto da inquisição. É um longo processo de viragens, que Lévi-Strauss abreviou muito.

Há mais. Em ambos os mitos 'prototípicos', balizadores das duas supostas vertentes da mítica postuladas pela teoria levistraussiana, o enigma é posto e abordado diretamente - o que não se verifica em todos, sequer na maioria dos mitos. Muito pelo contrário.

A rigor, seria o caso de se considerar as duas legendas em apreço "meta- míticas": de um modo quase insólito no campo mítico, elas sugerem uma problematização quando tematizam o enigma. Dá-se em ambas o descortino de um problema, ainda que seu foco explícito não corresponda à questão motriz da fábula. Por outro lado - e assim já passo a minha segunda consideração - será que, no universo dos mitos, estas duas formas "alternativas" de tratamento do enigma são, efetivamente, as únicas possíveis?
Sustento que não. Mas para defender minha tese, terei de imitar Lévi-Strauss. Começo recapitulando:

Édipo dá a resposta a uma pergunta enigmática. De imediato, escapa a um desastre - deixa de sofrer uma violência mortal, pois não é devorado pela Esfinge. Mas mediatamente seu êxito resulta em um desastre.

Percival cala uma pergunta sugerida por uma cena enigmática. Resulta a continuação de um desastre, ainda que o herói não sofra violência.

Uma terceira possibilidade seria a atuação de um personagem $X$ a quem se exige, sob ameaça de violência, resposta para perguntas enigmáticas - e primeiro responde, depois não responde, mas ao cabo tem êxito (escapa de um desastre, alcança um triunfo) por (finalmente) não responder.

Esta terceira possibilidade existe. Não a encontrei muito perto dos exemplos anteriores. Mas se, confiado na unidade do espírito humano, Lévi-Strauss comparou mitos de culturas diferentes, muito distanciadas tanto no espaço quanto no tempo, sinto-me autorizado por seu exemplo a fazer um salto semelhante. Tomarei o rumo da Índia antiga, evocando uma obra prima: o Vetalapankavimsatika. Recordarei brevemente o argumento básico desta novela em que se enredam vinte e cinco histórias. Essas histórias constituem uma longa cadeia de enigmas. No prólogo, descreve-se a situação inicial que engatilha os enredos. Passo ao resumo:

o Rei Trivikramasena recebe, durante vários dias seguidos, a homenagem de um mendigo chamado Ksantila, que invariavelmente the faz dom de uma fruta, logo entregue pelo soberano a seu tesoureiro. Sucede que um dia o monarca, tendo o ofertante saido da sala, dá a fruta a um macaquinho amestrado; quando este começa a comê-la, salta da casca da fruta uma jóia de grande valor. 0 rei indaga do tesoureiro onde guardara as frutas recebidas anteriormente; 0 ministro vai ao celeiro onde as depositava e constata que elas apodreceram, restando seu conteúdo: pedras preciosas esplêndidas. No dia seguinte, à chegada do mendigo, o rei lhe indaga o motivo dessas dádivas extraordinárias e Ksantila explica que deseja um favor do 
heroico soberano, coisa indispensável para a consumação de um encantamento. Para fazer-lhe o favor prometido, o rei, quatorze dias depois, vai a um cemitério onde o encontra a traçar um círculo mágico. 0 mendigo lhe pede para levar-lhe aí um cadáver que se achava em um local pouco distante, pendendo enforcado de uma árvore. 0 rei se dispõe a fazê-lo e tanto procura que acha o enforcado. Quando corta a corda, o cadáver volta ao lugar, e ele tem de pegá-lo de novo. Trivikramasena percebe que o defunto está possuído por um vampiro, um fantasma, porém trata de levá-lo assim mesmo. Logo o vampiro lhe dirige a palavra, propondo-se a contar-lhe uma história para distraí-lo no caminho. Narra-lhe então o primeiro conto, que encerra um problema. Concluída a narrativa, exige do rei a explicação, com a ameaça de fazer-lhe explodir a cabeça em cem pedaços se, sabendo, ele não the der a resposta verdadeira. 0 rei explica o enigma e o vampiro/ cadáver desaparece, de modo que Trivikramasena tem de ir buscá-lo de novo. Isto se repete vinte e quatro vezes. Na última, o rei interpelado fica em silêncio: não sabe dar resposta ao enigma intrincado da última história. Satisfeito, o vampiro então o livra de um desastre iminente: previne-o da traição do falso mendigo - que pretendia sacrificar o generoso soberano - e lhe ensina como escapar da armadilha, sacrificando, em vez, o embusteiro. ${ }^{19}$

Vale a pena retomar a comparação. Édipo é indagado (pela esfinge) e dá resposta adequada à questão enigmática. 0 fim de sua aventura será um desastre. Percival é provocado por um acontecimento intrigante e cala a pergunta que the propiciaria um grande êxito. Decorre um desastre, pois permanece uma situação de calamidade que poderia cessar com sua indagação.

Que sucede no caso de Trivikramasena? Ele é provocado por um acontecimento intrigante, como Percival: quando descobre que a oferenda "enigmática" do mendigo encobria uma dádiva ultra-generosa, o rei faz uma indagação. Nesse caso, é mesmo lícito falar de "acontecimento intrigante" e "dádiva enigmática": frutas efêmeras, aparentemente de pouco valor, encobrem jóias, ou seja, encerram bens duradouros e de valor excepcional. Essas preciosidades são dadas ao rei por um mendigo. Uma indagação se impõe: que significa a oferta velada? Pois o quadro intriga, "chama" pela pergunta.
À primeira vista, o problema parece ser "percivaliano". Mas se assim fosse, ao ser formulada pelo protagonista, a interrogativa acarretaria, de imediato, uma solução vitoriosa. Uma salvação. Trivikramasena indaga o que quer dizer a dádiva. Como prontamente adverte, a oferta envolve demanda. 0 doador logo declara o que deseja. Disso não decorre um êxito imediato, como o que Percival poderia alcançar indagando; tampouco sucede coisa parecida com o imediato fracasso vivido pelo Cavaleiro silencioso.

Na verdade, a pergunta do rei o compromete: implica o reconhecimento de que a dádiva insólita exige retribuição extraordinária. Ao enunciá-la, o rei se sujeita ao comando do mendigo. É que a isso o obriga sua heroica majestade. A dádiva compele. E assim o rei herói se submete a um grande risco. Percebemos também nós que a oferta do mendigo já era uma demanda: comportava um desafio, prenhe de perigos. Tendo aceito a demanda que o faz empenhar-se numa busca medonha, o rei, à semelhança de Édipo, é desafiado por um ser monstruoso: o híbrido de morto e vivo, o vampiro que the faz perguntas, como uma esfinge. Ele responde e não responde. Tem êxito só quando não responde.

Pode-se dizer que a história de Trivikramasena pertence ao campo erotemático, tanto quando 0 mito de Édipo e a aventura do Cavaleiro no reino de Anfortas. Quanto à estrutura, parece-me claro que essas narrativas se aparentam. Porém não vejo como enquadrar o belo conto do Vetalapankavimsatika na classificação proposta por Lévi-Strauss: não se pode dizer que esta seja uma história "edipiana", nem tampouco que constitua uma narrativa "percivaliana". Em todo o caso, na aproximação que fiz entre os três longínquos relatos poderia ler-se uma confirmação da tese de Lévi-Strauss: de certo modo, isso confirmaria a ousada aproximação/oposição que ele fez entre mitos de Édipo e de Percival. A história de Trivikramasena se articularia com essas outras compondo um triângulo revelador de uma espécie de macro-estrutura mítica. Não creio, porém, que no interior desse triângulo caiba toda a mitologia. Isso nunca foi demonstrado, nem parece demonstrável.

Por outro lado, a oposição entre "edipiano" e "percivaliano" é questionável. Como em outro
19. Mais tarde, o Vampiro benévolo explica ao rei que 0 falso mendigo o imolaria a fim de tornar-se soberano dos espíritos aéreos. Acrescenta que o próprio Trivikramasena terá este posto, depois de concluído seu reinado terrestre. É interessante notar que o enigma não resolvido tem a ver com algo muito semelhante a um incesto. 
lugar assinalei (SERRA 2007, p. 3308), numa das versões da história de Percival ele tem uma segunda oportunidade e faz a pergunta salvadora; nem por isso devém incestuoso.

20. 0 enigma do tipo mais comum tampouco corresponde ao tipo de problema dito intratável por conta do número e do intrincamento de operações que exige realizar a fim de resolver-se, como sucede no caso dos "intratáveis" da teoria da complexidade computacional. 0 enigma sempre tem uma estrutura simbólica simples... É percebido como uma aporia; mas nos mitos geralmente se pressupõe que adivinha não deve ser insolúvel.

De qualquer modo, aporias também são expostas na mítica.

21. Cf. fr. 18 (DK)

No fragmento 93 (DK), Heráclito evoca o deus oracular que era chamado de Lóxias ("Oblíquo") por causa de seus responsos "tortuosos". Assim ele se refere a Apolo: “0 deus cujo oráculo está em Delfos não diz nem cala; dá sinais". Com isso, o filósofo assinala seu modelo excelso. Será pertinente chamar de "enigmático" o Logos heracliteano? Haverá quem diga que sim, dada a dificuldade de compreender suas sentenças - dificuldade que Sócrates (ninguém os enigmas da classe a que Lévi-Strauss dá este nome. Um bom exemplo vem a ser o que Céfalo confronta no seu embate com a raposa de Teumesso, que também diziam ter sido caçada por Édipo (SERRA, 2007).

No caso típico de discurso problematizador, menos!) já confessava experimentar.

0 enigma típico envolve a injunção de reunir pergunta e resposta superando embaraços no caminho de sua adequação. Essa injunção geralmente é dada como condição de franquia de uma possibilidade encarecida, de modo tal que implica a decisão de uma alternativa, clara ou velada. Assim, o enigma típico costuma ter, também, um "custo" prático, como já se disse: envolve um impasse associado à exigência de uma passagem necessária. Corresponde a esse tipo de enigma a injunção de contestar, com a contra-senha adequada, à interpelação de uma sentinela. Quem erra não passa. E pode até morrer. Bem assim, a adivinha que a Esfinge propõe envolve um repto: respondê-la é a condição para ir adiante, evitar a morte.

Reconhece-se, nessas instâncias, a estrutura característica do sýmbolon. A resposta oferecida a Percival também lhe significava uma condição que, se satisfeita - através do enunciado da pergunta correspondente - lhe garantiria um êxito "conclusivo".

Nesses casos, que são os mais típicos, 0 enigma tem uma solução previamente estabelecida, controlada por quem o propõe. Se não envolve 0 controle prévio da resposta por parte do propositor, será antes um problema, qualificável de "enigmático" em função do seu grau de dificuldade.

Em princípio, nos jogos rituais e em grande número de mitos, o enigma deve ter solução. Caso contrário, constituirá uma aporia. ${ }^{20}$ São "aporéticos" a pergunta é levada até sua resposta, ou, quando nada, a tentativas sistemáticas de responder. No mínimo (na pior das hipóteses), trata-se logo de reconhecer explicitamente a impossibilidade de contestá-la, isto é, de resolver o problema, provisória ou definitivamente.

A escrita de Heráclito não é enigmática no sentido mais comum do termo, embora em sentido figurado ela se mostre assim. Tampouco tem o corte analítico usual do discurso problematizador - e isto seguramente não se deve a uma incapacidade do filósofo. A maneira como Heráclito lida com contradições de fato inconciliáveis não conduz à verificação de aporias, nem à solução delas de modo a dissipá-las. Nem por isso é irracional. Será melhor qualificá-la de loxíaca.

0 deus chamado de Loxias, muitas vezes, dava a seus consulentes respostas oraculares que geravam perplexidade. A correspondência dessas respostas com as indagações feitas à pitonisa não era clara, tinha sempre um quê de inesperado. Ora, Heráclito indica o modo como o deus responde: "dá sinais". Segundo rezam as histórias délficas, esses sinais pareciam transcender o disposto na pergunta, não se acomodavam a ela. Exigiam um entendimento capaz de ultrapassar a expectativa imediata da questão.

Pode-se dizer que a linguagem apolínea transborda. Seus sinais vão além da fala e do silêncio, da divisão entre fala e silêncio. Neste caso, o "enigma" se acha na ultrapassagem da questão, levada mais além de si mesma. Pode resultar perplexidade dessa violação dos limites do arrazoado expectante da indagação. Mas é preciso manter-se atento: “Quem não espera o inesperado não o achará". ${ }^{21}$

Heráclito imita o deus. Também ele dá sinais, acena. De que modo? Hermann Fränkel iluminou seu procedimento em um magnífico estudo, que serviu de ponto de partida ao helenista brasileiro Eudoro de Sousa para uma abordagem inovadora do pensamento do grande efésio. ${ }^{22}$ Deve-se a Fränkel a descoberta de 
um padrão que estrutura a maior parte das sentenças heracliteanas: o do "meio proporcional". Nesse arranjo, o enunciado se dispõe em progressão. Parte-se da relação perceptível entre dois termos conhecidos e se lhe correlaciona outra, entre o mais ascendente na primeira correspondência e um último termo. 0 sentido assim sugerido deste termo é o que se quer dar a pensar; é o sentido para o qual o filósofo acena.

Ora, podem ser correlacionados assim termos opostos. A coincidentia oppositorum devém a base de uma significação que excede a experiência comum. Eudoro de Sousa mostrou-,o aproximando diversos fragmentos heracliteanos ${ }^{24}$ em que o filósofo joga com a oposição de sono e vigília. [De sua análise conjunta pode-se inferir a proporção: 0 sono está para a vigília assim como a vigília está para $x$ (em que $x$ indica algo não apreensível no mesmo horizonte, algo que transcende o campo empírico)]. A esta oposição ainda se pode correlacionar a de morte e vida (fr. 26): o helenista o demonstrou, comparando o fragmento 1 e 0 26. E uma leitura atenta do fragmento 1 permite ir além: desvela a correspondência entre estes contrastes e os de olvido e memória (fr. 1). A mesma equação simbólica se encontra na poesia de Dante Alighieri, segundo mostrei em outro estudo (2002). ${ }^{25}$

Sublinho a última correlação apontada: aquilo que transcende olvido e memória (e sono e vigília) não tem nome na fala de Heráclito. No entanto, não é descabido pensar em Mnemósine a propósito deste aceno loxíaco: bem a compreende o deus de Delfos, o Musageta, capaz de reversa harmonia "como a do arco e da lira".

Impossivel não reconhecer que o mito ainda fala pela boca do profeta do Logos. E sua música não cessa com a filosofia.

Nem com a ciência.

\section{REFERÊNCIAS BIBLIOGRÁFICAS}

AGAMBEN, G (2006). A linguagem e a morte. Belo Horizonte, Editora UFMG.

ANONYME (1963). Contes du Vampire. Paris, Gallimard.

BACHELARD, G. (2002). Filosofia do Novo Espirito Científico. Lisboa, Editorial Presença.

DORFLES, G (1988). Elogio da desarmonia. Lisboa, Edições 70.
FRÄNKEL, H (1938). "A thought pattern in Heraclitus". American Jornal of Philology, v. 59, p. 309-337.

HYMES, D (2006). Foundations in Sociolinguistics: an Ethnographic Approach. Piladelpia, University of Pensilvania Press, 1974. KIERKGAARD, S. A. $O$ conceito de ironia constantemente referido a Sócrates. Bragança Paulista: Editora Universitária São Francisco.

LATOUR, C.-H. P. de (2004). "La conception lévistraussienne de l'inceste: sapertinence et ses prolongements". L'Herne. Cahier dirigé par M. Izard. Paris, Éditions l'Herne, p.179-187.

LÉVI-STRAUSS, C (1962). La pensée sauvage. Paris, Plon. (1966). Du miel aux cendres. Paris, Plon.

(1974). "Introdução à obra de Marcel Mauss"; In. Sociologia e Antropologia. I. São Paulo, E.P.U / EDUSP.

(1976). Antropologia Estrutural II. Rio de Janeiro, Tempo Brasileiro.

(1984). Paroles Données. Paris, Plon.

(2004). "Les mathématiques de l'homme". L'Herne. Cahier dirigé par M. Izard. Paris, Éditions l'Herne, p. 25-31.

(2004a). "Pensée mythique et pensée scientifique". L'Herne. Cahier dirigé par M. Izard. Paris, Éditions l'Herne, p. 40-2.

LÉVI-STRAUSS, C. \& ÉRIBON, D (1990). De perto e de longe. Rio de Janeiro, Nova Fronteira.

MARANDA, E. K (1971). "The logic of riddles."; In. Structural analysis of oral tradition. Philadelphia, University of Pennysilvania Press, p. 190-231.

NIETZSCHE, F (2008). A filosofia na era trágica dos gregos. São Paulo, Hedra.

SCHELLING, F.W. J. (1986). Philosophie der Mythologie. Darmstadt, Wissenschaftliche Buch Geselschaft.

SERRA, 0. (2002). Veredas. Antropologia Infernal. Salvador, EDUFBA.

(2005). "À luz da tragédia: Édipo e o apotropaico". Mana 11 (2), p. 545-576.

(2007). 0 reinado de Édipo. Brasília: EDUNB.

SOUSA, E. (1975). Horizonte e Complementariedade. São Paulo, Duas Cidades. 